\title{
Life cycle assessment of biodiesel from soybean, jatropha and microalgae in China conditions
}

\author{
Jian Hou ${ }^{\mathrm{a}, \mathrm{b}}$, Peidong Zhang ${ }^{\mathrm{a}, *}$, Xianzheng Yuan ${ }^{\mathrm{a}, \mathrm{b}}$, Yonghong Zheng ${ }^{\mathrm{a}}$ \\ a Qingdao Institute of Bioenergy and Bioprocess Technology, Chinese Academy of Sciences, Shandong Province, Qingdao 266101, China \\ ${ }^{\mathrm{b}}$ Graduate University of Chinese Academy of Sciences, Beijing 100049, China
}

\section{A R T I C L E I N F O}

\section{Article history:}

Received 27 December 2010

Accepted 5 July 2011

Available online 15 September 2011

\section{Keywords:}

Biodiesel

Soybean

Jatropha

Microalgae

Environmental impacts

China

\begin{abstract}
A B S T R A C T
Increasing demand for transport fuels has driven China to attach great importance to biodiesel development. To evaluate the environmental impacts caused by producing and driving with biodiesel made from soybean, jatropha, and microalgae under China conditions, the LCA methodology is used and the assessment results are compared with fossil diesel. The solar energy and $\mathrm{CO}_{2}$ uptake in biomass agriculture and reduction of dependency on fossil fuels lead to a better performance on abiotic depletion potential (ADP), global warming potential (GWP), and ozone depletion potential (ODP) in the life cycle of biodiesel compared to fossil diesel. Except for ADP, GWP and ODP, producing and driving with biodiesel does not offer benefits in the other environmental impact categories including eutrophication, acidification, photochemical oxidation, and toxicity. Jatropha and microalgae are more competitive biodiesel feedstock compared to soybean in terms of all impacts. By using global normalization references and weighting method based on ecotaxes, the LCA single score for the assessed 10 mid-point impact categories of soybean, jatropha, and microalgae based biodiesel is 54, 37.2 and 3.67 times of that of fossil diesel, respectively. Improvement of biomass agriculture management, development of biodiesel production technologies, bettering energy structure and promoting energy efficiency in China are the key measures to lower environmental impacts in the life cycle of biodiesel in the future. Various sensitivity analyses have also been applied, which show that, choice of allocation method, transport distance, uncertainty in jatropha and microalgae yield and oil content, and recycling rate of harvest water of microalgae have significant influence on the life cycle environmental performance of biodiesel.
\end{abstract}

(c) 2011 Elsevier Ltd. All rights reserved.

\section{Contents}

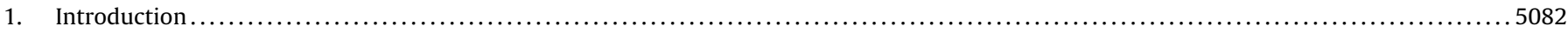

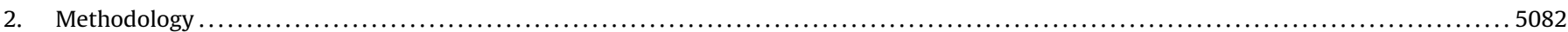

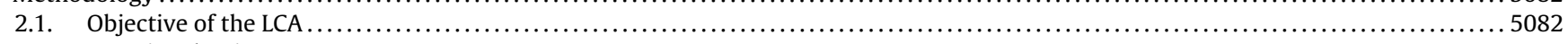

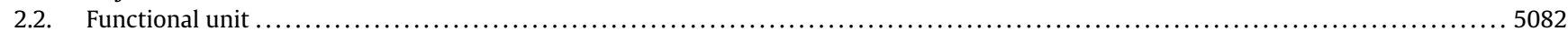

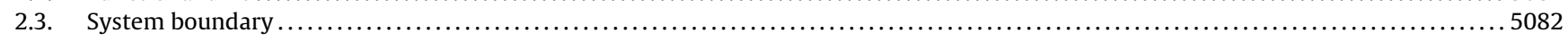

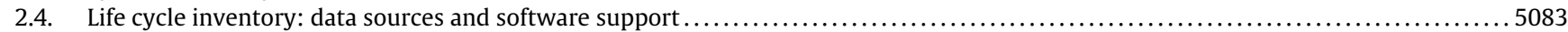

2.5. Life cycle inventory: allocation.

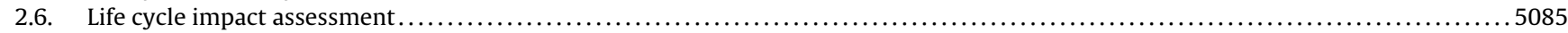

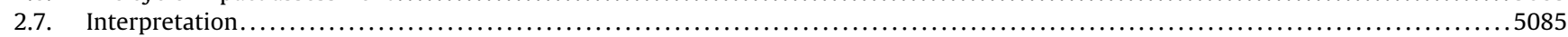

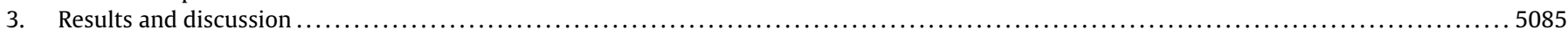

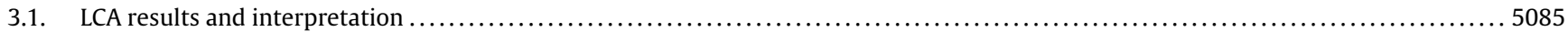

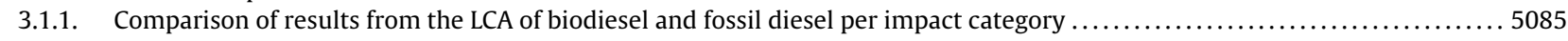

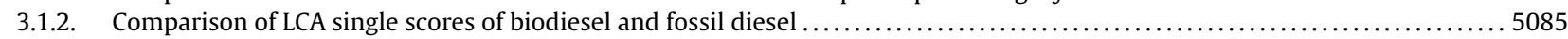

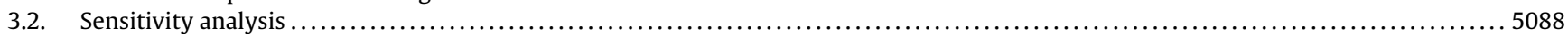

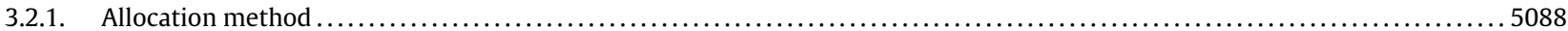

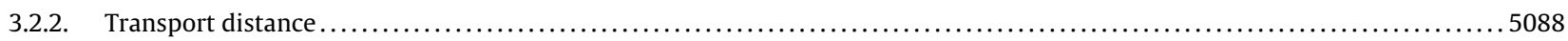

\footnotetext{
* Corresponding author. Tel.: +86532 80662790; fax: +8653280662778.

E-mail address: eeesc@163.com (P. Zhang).
} 


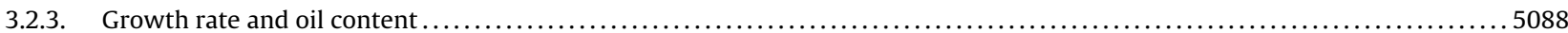

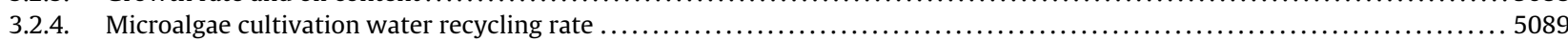

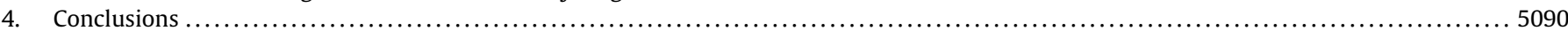

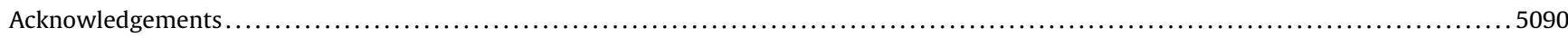

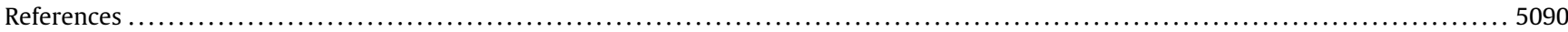

\section{Introduction}

In China, in 2009, the national crude oil consumption reached 388 million tons and imported crude oil provided $51.29 \%$ of consumption [1]. An increasing demand for transport fuels has not only led to an increase in the price of crude oil but also an increased risk for depletion of fossil resources [2]. Besides, conventional crude oil derived fuels have since long been pointed out as contributors to environmental impacts such as global warming [3]. The development of biofuels as transport fuel has the potential to reduce both greenhouse gas (GHG) emissions and the reliance on fossil fuels [4]. Biodiesel as the most potential biofuel to substitute fossil diesel as a transport fuel has received great attention in China. According to the Medium and Long-term Development Plan for Renewable Energy issued by the National Development and Reform Commission on August 31,2007, the amount of biodiesel usage in China will amount to 0.2 million tons in 2010 and 2.0 million tons in 2020 [5].

Typical raw materials of biodiesel are edible oils like soybean oil, rapeseed oil, sunflower oil, and palm oil. In China the biggest biodiesel producers adopt rapeseed and soybean oil as raw material [6]. To avoid conflict in demand between food and energy, wild energy plants and microalgae have been researched recently to yield oils for biodiesel production $[7,8]$. To identify the sustainability of diesel produced by biomass feedstock to substitute fossil resource derived diesel as a transport fuel, extensive analyses for environmental performances of biodiesel have been emerged [9-14]. The research by Bernesson et al. [10] shows that, for small plants and by physical allocation, the global warming potential is $40.3 \mathrm{~g} \mathrm{CO}_{2}$-equiv./MJ rape methyl ester produced, the acidification potential $236 \mathrm{mg} \mathrm{SO}_{2}$-equiv./MJ fuel, the eutrophication potential $39.1 \mathrm{mg} \mathrm{PO}_{3}{ }^{4-}$-equiv./MJ fuel, the photochemical oxidant creation potential $3.29 \mathrm{mg} \mathrm{C}_{2} \mathrm{H}_{4}$-equiv./MJ fuel and the energy requirement $295 \mathrm{~kJ} / \mathrm{MJ}$ fuel. Harding et al. [11] uses the life cycle assessment (LCA) to compare inorganic and biological catalysis for the production of biodiesel from rapeseed oil by transesterification, and the LCA shows that the enzymatic production route is environmentally more favourable, in which improvements are seen in all impact categories. Lardon et al. [12] provides an analysis of the potential environmental impacts of biodiesel production from microalgae, and the outcome confirms the potential of microalgae as an energy source but highlights the imperative necessity of decreasing the energy and fertilizer consumption.

Contrary to that oil is the world's dominant fuel [15], the total proved coal reserve in China is 114,500 million tons [16] and contributes about $70 \%$ to the primary energy production and total energy consumed [17]. The energy input and pollutant emission balance for biodiesel production in China would be quite different to the cases of economically developed countries with improved energy structure and higher energy efficiency.

Previous LCA studies of biodiesel in China focus on fossil energy consumption and greenhouse gas emissions [18-23]. However, the environmental impacts generated in the life cycle of biodiesel do not only include fossil energy resource depletion and global warming. Other impact categories should also be taken into account to evaluate the sustainability of biodiesel comprehensively. This study carries out a life cycle assessment on biodiesel made from soybean oil, jatrophal oil, and microalgal oil in China conditions to evaluate the environmental performance of producing and using biodiesel as transport fuel compared with fossil diesel with a more complete set of impacts.

\section{Methodology}

\subsection{Objective of the LCA}

The main objective of the LCA in this study is to quantify and compare the environmental impacts by producing and driving with biodiesel derived from soybean oil, jatrophal oil, and microalgal oil in China conditions, with a view to their potential use as alternative transport fuel of fossil diesel. Additional objective is to identify the most important environmental loads and effective parameters in these biodiesel life cycle systems, helping to suggest measures for improvement.

\subsection{Functional unit}

In LCA, the functional unit (FU) provides a reference to which the inputs and outputs are related. According to that biodiesel has similar combustion characteristics with conventional fossil diesel, the functional unit for the LCA in this study is $1 \mathrm{MJ}$ of energy from bioand fossil diesel "well-to-wheel". This justifies a direct comparison of fuels based on their calorific value.

\subsection{System boundary}

Fig. 1 shows the life cycle system of biodiesel including all relevant processes causing resources use and pollutants emission: production of chemicals and process energy, agriculture of biomass feedstock, production of biodiesel, biomass and biodiesel transport sections, and final vehicle operations.

The soybean and jatropha agriculture process is built from the study by Ou [21]. Industrial-scale facilities for biodiesel production from microalgae have not been built yet. The microalgae cultivation process is built from a nearly complete design for a large production system to produce biodiesel from algae by Regan [24] and Benemann [25]. However, to provide a more realistic approach in the management of jatropha agriculture, a modification is made: jatropha contains a variety of bioactive substances which have well insecticidal effect, and in the study of Ou [21], the agrochemical input is not considered. However, from the literature [26], it appears that application of agrochemicals to jatropha is still needed to resist stem rot and insect damage of shootmoth and Chinese Cricket. Annually, fungicides and pesticides are assumed to be applied in jatropha agriculture.

The conversion of soybean, jatrophal and microalgal oil to diesel consists of steps of vegetable oil extraction, feedstock pretreatment, transesterification, methanol recycling, and crude methyl ester purification. Oil is extracted from cleaned rapeseed, jatropha seeds and microalgae. Crude vegetable oil is pretreated with processes of deacidification, degumming and drying to remove residual free fatty acids, phospholipids and water. Biodiesel is produced through transesterification of refined vegetable oil and methanol in the conditions of catalysis, heating and pressurizing. Excessive methanol is recycled. Crude methyl ester is treated by washing, fractionation, and drying to obtain biodiesel end product. 


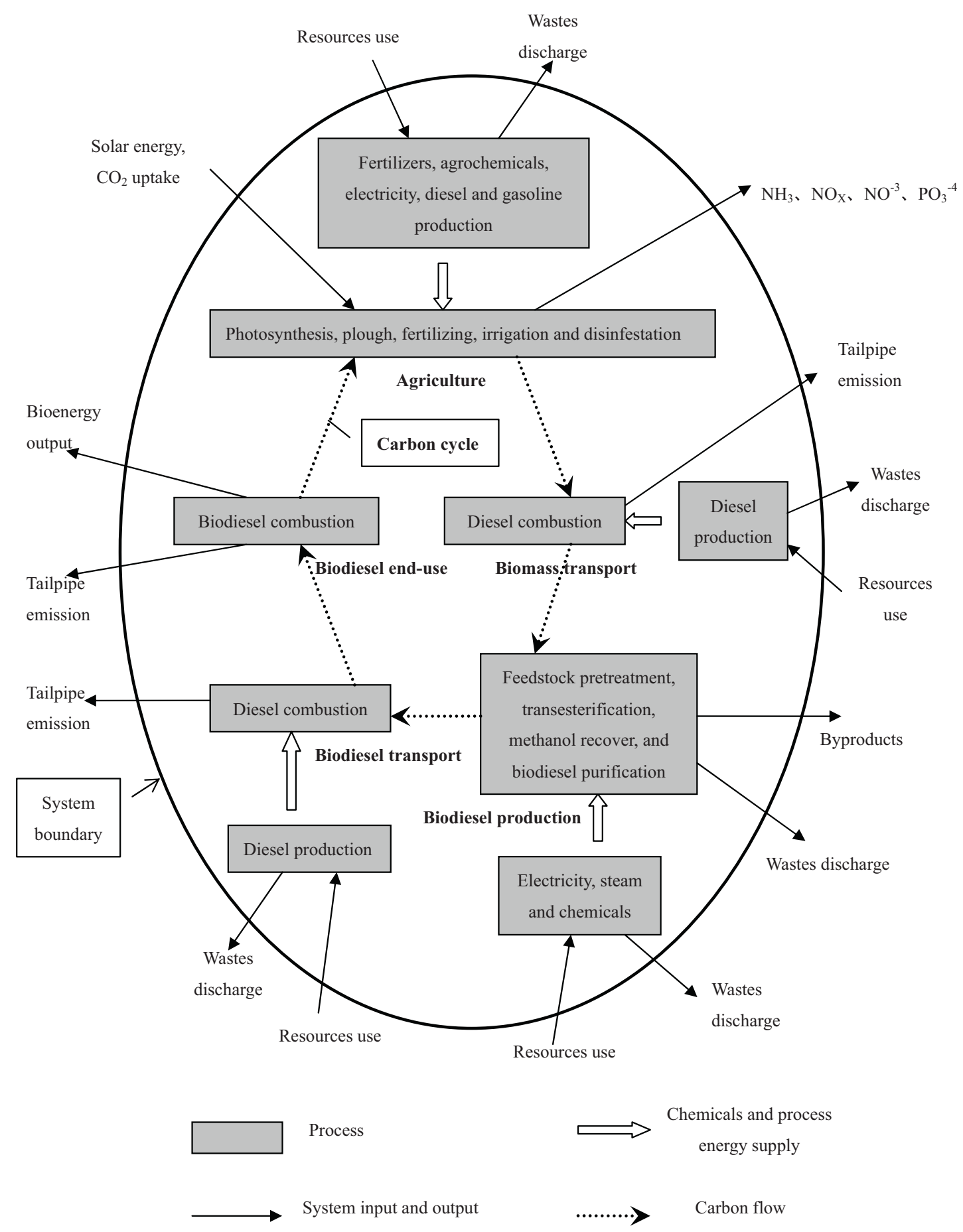

Fig. 1. Life cycle system of biodiesel.

The transport of feedstock and product is by road using lorry with various loading capacities. The end-use stage of biodiesel fuel life cycle is fuel combustion via vehicle operation.

\subsection{Life cycle inventory: data sources and software support}

Data are mainly derived from recent studies on relevant processes included in biodiesel life cycle system. Gabi 4.3 program [27] is used to calculate the base data. All the inputs, product outputs, and emissions in the life cycle of different feedstock based biodiesel are summarized in Table 1.
Background data include inputs and outputs in processes for the production of accessory materials and process energies, such as production of steam, electricity, fertilizers, diesel, pesticides, and methanol. Background data are normally incorporated in international databases, but sometimes the conditions of the processes (e.g. energy structure, energy efficiency etc.) are different. In these cases, we compiled data from studies on the background processes under China conditions as follows: electricity [37], gasoline and diesel [38], nutriments [39-41], agrochemicals [42], and methanol [43]. The background data for steam production in China can be found in Gabi database. 
Table 1

Inputs, outputs, and emissions in the life cycle system of soybean, jatropha, and microalga based biodiesel.

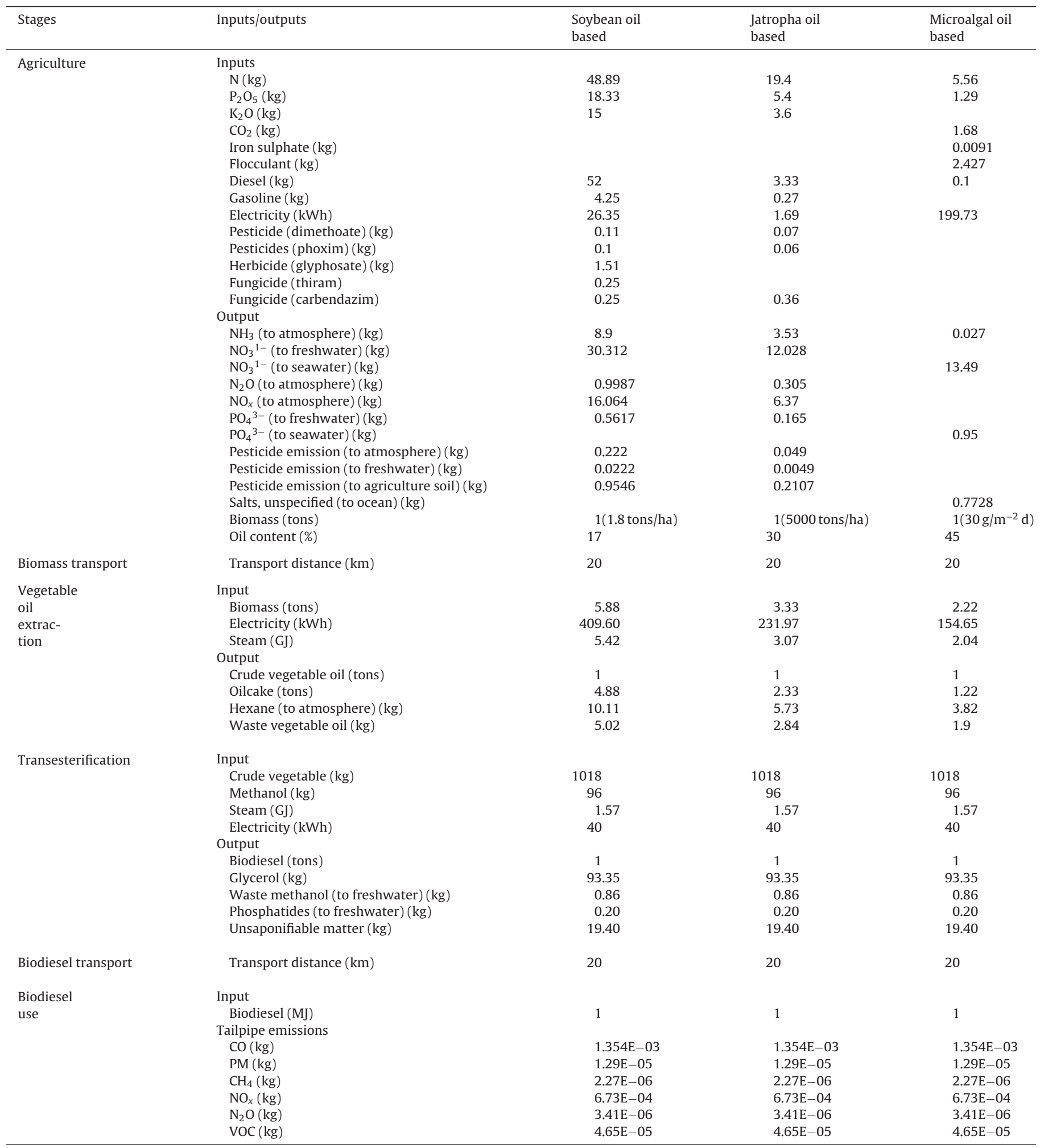

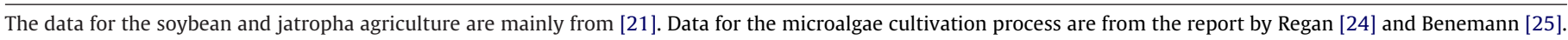

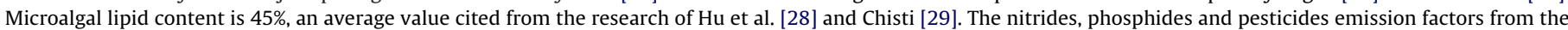

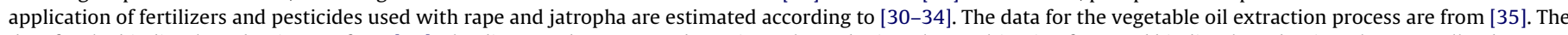

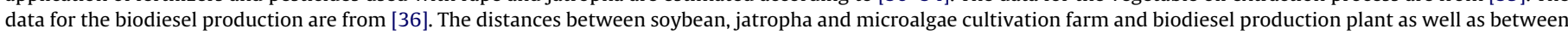

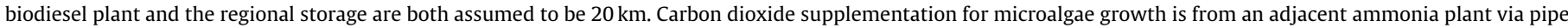
in pure form. The data for the biodiesel combustion are from Gabi database, which are similar to fossil diesel. 


\subsection{Life cycle inventory: allocation}

When biodiesel is produced, oilcake and crude glycerol are co-generated. For multifunctional systems in LCA, allocating the material and energy inputs and environmental emissions between the main- and co-products is a necessary issue. In this study, allocation based on mass of the products-vegetable oil, rapeseed cake, jatropha seed cake, algae residues, biodiesel and crude glycerol, is applied.

\subsection{Life cycle impact assessment}

CML Leiden 2001 is used in this study to assess the potential environmental impacts generated in the life cycle system of biodiesel [44]. The following mid-point impact categories have been assessed:

\author{
Abiotic depletion potential (ADP) \\ Global warming potential (GWP) \\ Ozone depletion potential (ODP) \\ Photochemical oxidation potential (POCP) \\ Acidification potential (AP) \\ Eutrophication potential (EP) \\ Human toxicity potential (HTP) \\ Fresh water aquatic ecotoxicity potential (FAETP) \\ Marine aquatic ecotoxicity potential (MAETP) \\ Terrestric ecotoxicity potential (TETP)
}

\subsection{Interpretation}

A contribution analysis is performed to understand the contributions of specific processes and pollutants to the total impact scores per impact category, and to find the reasons of the changes of environmental impacts between fossil diesel and biodiesel. Furthermore, various sensitivity analyses, determining the influence of the variations in assumptions, method choices, and process data on the results, have been applied $[45,46]$.

\section{Results and discussion}

\subsection{LCA results and interpretation}

\subsubsection{Comparison of results from the LCA of biodiesel and fossil diesel per impact category}

The comparative results from the LCA of soybean, jatropha, and microalgae based biodiesel and fossil diesel per impact category are shown in Fig. 2. Fig. 3 shows the relative contributions of all relevant processes to the LCA environmental impacts within each category. $\mathrm{SB}, \mathrm{JB}, \mathrm{MB}$ represents for soybean, jatropha, and microalgae based biodiesel respectively, and FD represents for fossil diesel.

As can be seen in Fig. 2, the life cycle of biodiesel consume less fossil resources compared to fossil diesel, and less GHG emissions are produced. The life cycle ADP of soybean, jatropha, and microalgae based biodiesel decreases by $70.05 \%, 82.32 \%$, and $80.94 \%$ compared with fossil diesel, respectively, and GWP decreases by $61.67 \%, 80.35 \%$, and $82.19 \%$, respectively. The primary reason of this significant decrease is the large amount of solar energy and $\mathrm{CO}_{2}$ uptake in biomass growth. Compared to fossil diesel, producing biodiesel can reduce the use of crude oil, which is the primary source for fossil diesel production. Emissions from crude oil extraction and refining are avoided, causing a significant decrease in impact of ODP in producing biodiesel.

Fig. 2 indicates that, except for GWP, ADP, and ODP, producing and using biobased diesel does not offer advantages over fossil diesel regarding other environmental impacts. Life cycle photo- chemical oxidation potential of soybean, jatropha, and microalgae based biodiesel increases $143.43 \%, 101.83 \%$ and $92.66 \%$ compared to fossil diesel respectively. As can be seen in Fig. 3, given that biodiesel has similar combustion emissions with conventional fossil diesel, the higher level of POCP caused by producing and using biodiesel fuels is mainly due to the hexane emission during vegetable oil extraction, which contributes $24.1 \%$, $29 \%$ and $30.4 \%$ to the life cycle POCP of soybean, jatropha, and microalgae based biodiesel, respectively.

Eutrophication potential in the life cycle of soybean, jatropha, and microalgae based biodiesel is 3.96, 2.25 and 1.53 times of the life cycle EP of fossil diesel, respectively. Acidification potential in the life cycle of soybean, jatropha, and microalgae based biodiesel is 2.97, 1.92 and 1.37 times of the life cycle AP of fossil diesel, respectively. The higher eutrophication and acidification potential in the life cycle system of biodiesel are mainly caused by the upstream emissions of nitrate and phosphate leaching to ground water, and ammonia and nitric oxide $\left(\mathrm{NO}_{x}\right)$ to air from $\mathrm{N}$ and $\mathrm{P}$ fertilizer application. Biomass agriculture contributes $68.01 \%, 45.45 \%$ and $34 \%$ to the life cycle EP of soybean, jatropha, and microalgae based biodiesel respectively, and $47.33 \%$ and $28.07 \%$ to AP of soybean and jatropha based biodiesel, respectively. Agriculture is also the main contributor to freshwater aquatic and terrestrial ecotoxicity potential in the life cycle of soybean and jatropha derived biodiesel, due to the use of agrochemicals.

Human toxity and marine aquatic ecotoxity potential in the life cycle of soybean, jatropha, and microalgae based biodiesel are largely contributed by processes of chemicals, steam and electricity production. Coal occupies a dominant role in primary energy supply in China. Compared to oil, much more heavy metals and hydrogen fluoride are discharged in the extraction and processing of coal, which cause significant impacts in terms of HTP and MAETP.

It is obvious that jatropha and microalgae are more environmentally competitive when compared to soybean as feedstock of biodiesel in terms of all impacts. The better life cycle environmental performance of jatropha and microalgae based biodiesel is mainly a result of the lower level of agricultural inputs per unit of oil output than soybean. Especially, microalgae based biodiesel shows very low impacts for FAETP and TETP attributed to the absence of toxic agrochemicals in microalgae cultivation. However, about $8 \%$ increase of ADP is for microalgae based biodiesel compared to jatropha based biodiesel due to consuming much more electricity in microalgae cultivation.

\subsubsection{Comparison of LCA single scores of biodiesel and fossil diesel}

Decision makers often consider multiple objectives that conflict or trade-off across a set of decision options: one option dominates the others for one objective but is itself dominated for another objective. To identify the most preferable decision option, one relatively weights the importance or value of different objectives and aggregates them into a single composite score [47].

The LCA results of biodiesel for these 10 mid-point impact categories are further combined into a single score using normalization references and weighting factors. Although the biodiesel researched in this study is produced under China conditions, to compare and make options from different biomass feedstock based biodiesel and fossil diesel from a broad and candid perspective, global normalization and weighting factors are used. Normalization factors in this study are calculated according to Sleeswijk et al. [48]. The relative weighting of different impact categories can be decided by panel methods, monetisation methods, distance-totarget methods etc. The presented assessment uses a monetisation approach aiming to express the society's view on which damages or potential impacts are of greatest importance in a monetary measure [49]. Weighting factors based on ecotaxes are implemented according to Finnveden et al. [50]. This final score is expressed as 

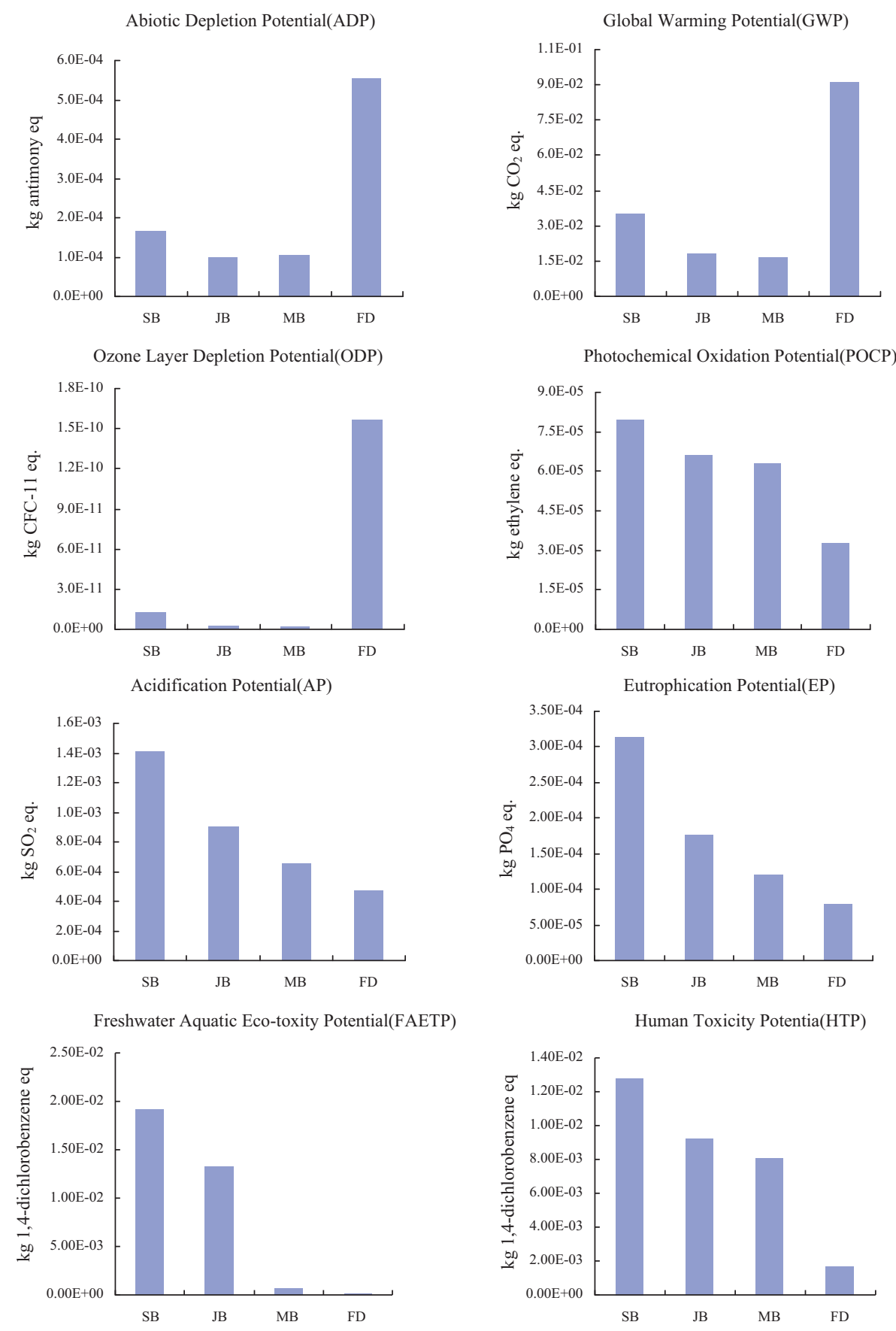

Marine Aquatic Ecotoxity Potential(MAETP)

Terrestrial Ecotoxity Potential(TETP)
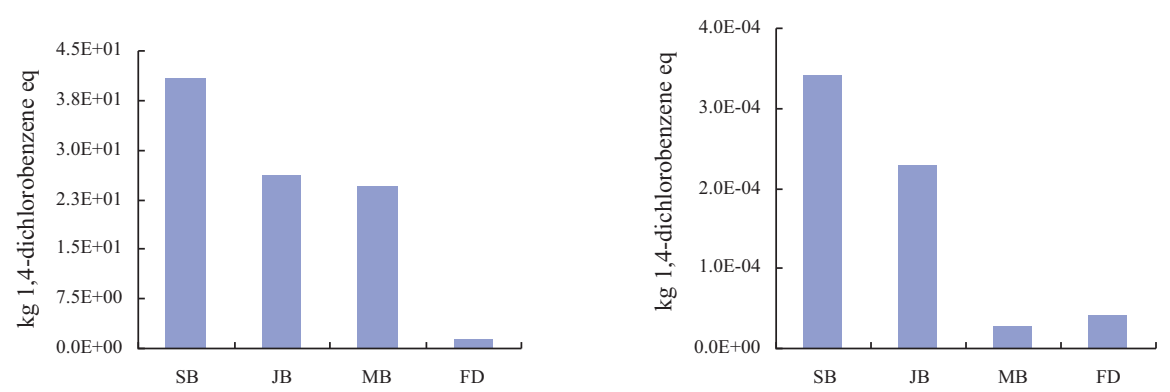

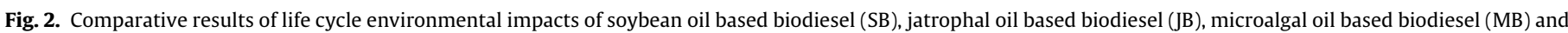
fossil diesel (FD). 
Relative contributions of technological elements to the life cycle environmental impcats of SB.

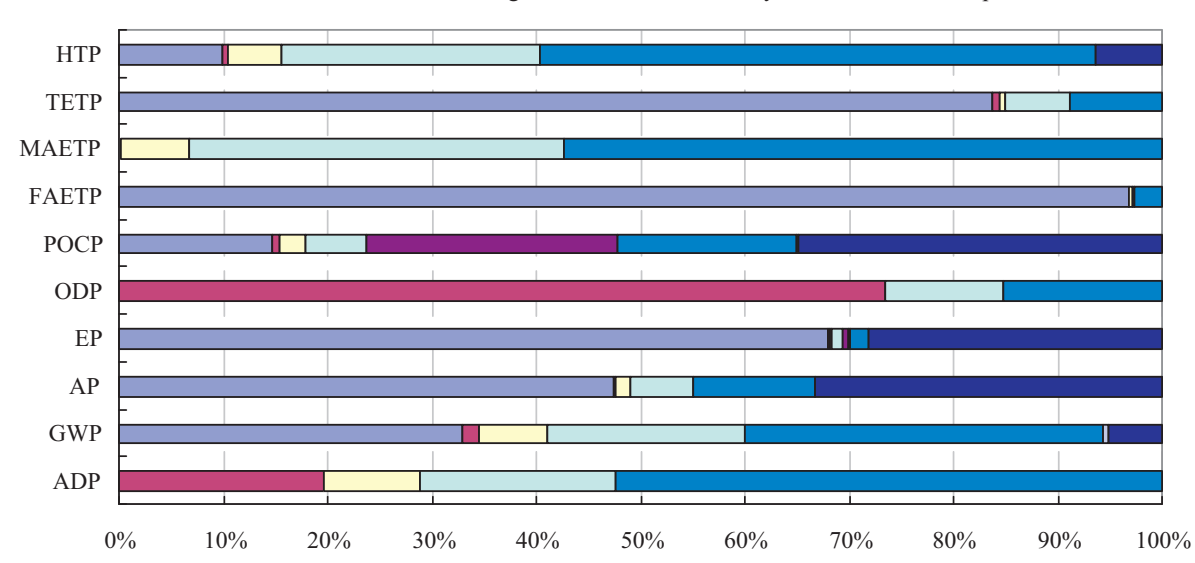

$\begin{array}{lll}\square \text { biomass cultivation } & \square \text { fossil transport fuels production } & \square \text { power production } \\ \square \text { heat production } & \square \text { vegetable oil extraction } & \square \text { transesterification } \\ \square \text { chemicals production } & \square \text { transportation } & \square \text { biodiesel combustion }\end{array}$

Relative contributions of technological elements to the life cycle environmental impcats of JB

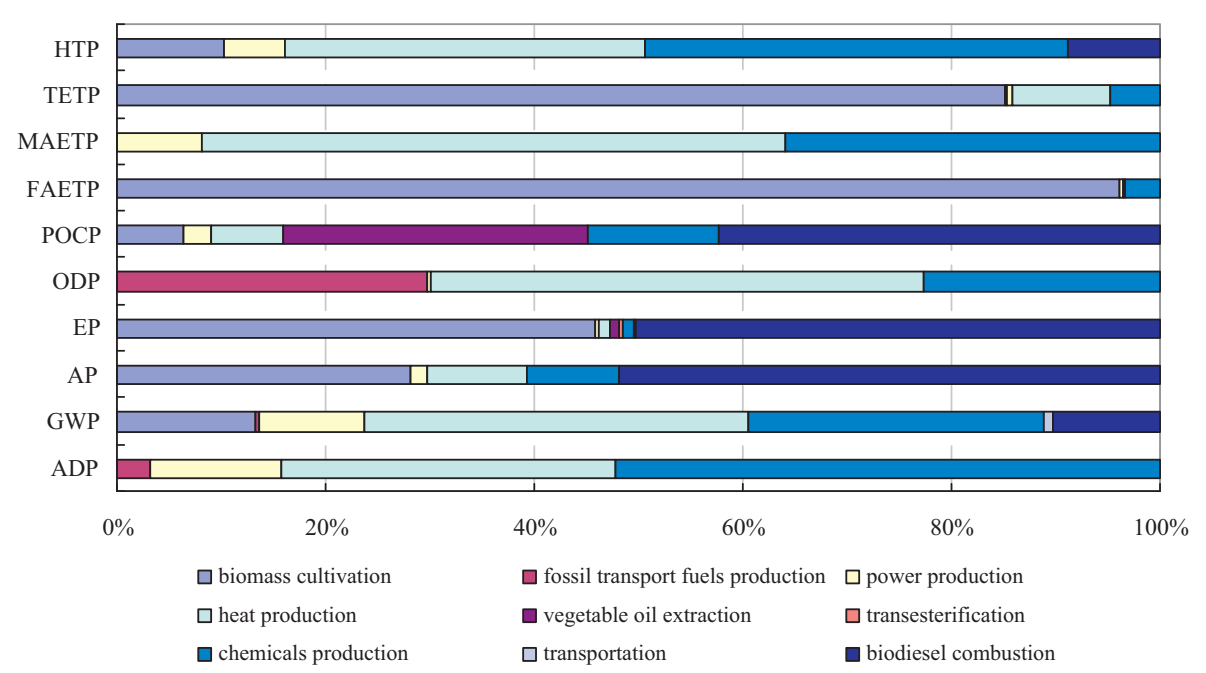

Relative contributions of technological elements to the life cycle environmental impcats of MB

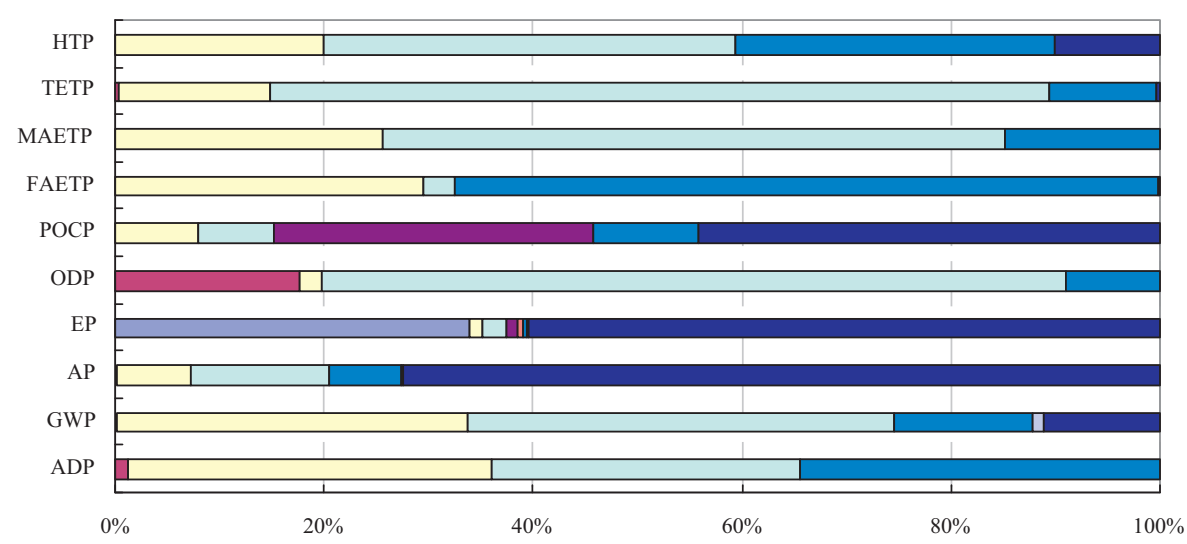

$\begin{array}{lll}\square \text { biomass cultivation } & \square \text { fossil transport fuels production } & \square \text { power production } \\ \square \text { heat production } & \square \text { vegetable oil extraction } & \square \text { transesterification } \\ \square \text { chemicals production } & \square \text { transportation } & \square \text { biodiesel combustion }\end{array}$

Fig. 3. Relative contributions of the relevant processes to the total scores within each environmental impact category. 


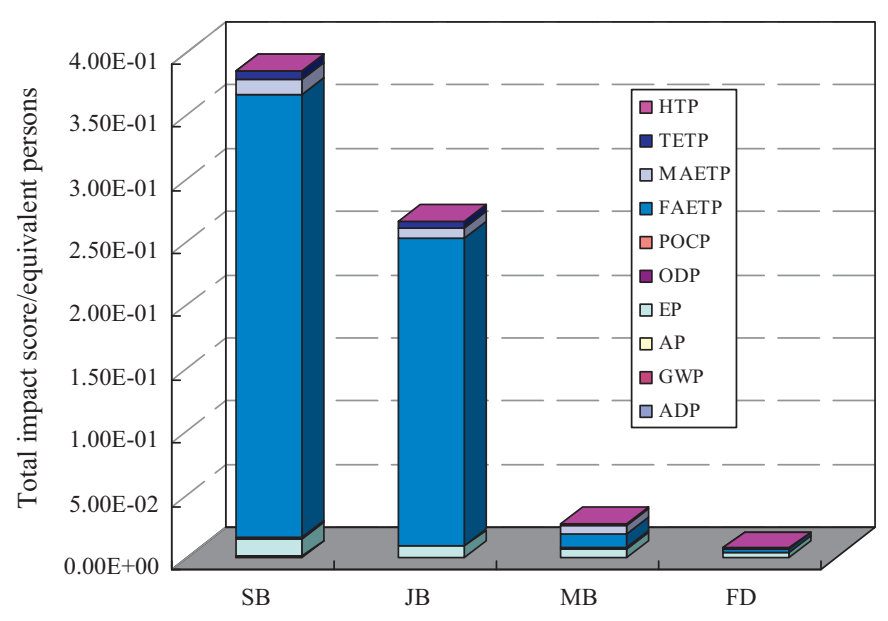

Fig. 4. Comparison of LCA single scores of biodiesel and fossil diesel.

equivalent persons, which can be interpreted as the number of equivalent persons affected during one year per unit of emission [51].

As can be seen in Fig. 4, freshwater aquatic ecotoxicity potential contributes $90.97 \%, 91.89 \%$ and $43.96 \%$ to the total environmental impact in the life cycle of soybean, jatropha, and microalgae based biodiesel respectively; LCA single score for these $10 \mathrm{mid}$ point impact categories of soybean, jatropha, and microalgae based biodiesel is 54, 37.2 and 3.67 times higher than that of fossil diesel respectively.

\subsection{Sensitivity analysis}

\subsubsection{Allocation method}

Oil meals and crude glycerol are coproduced in the vegetable oil extraction and transesterification processes respectively. As stated in ISO $14040-44$ series [46,52], whenever more than one allocation method can be applied, a sensitivity analysis is required. In this case, in order to understand the influence of different allocation methods in LCA study, allocation based on energy content is also applied and compared with mass-based partition. The partitioning ratios between main- and co-products outputted in the life cycle system of biodiesel are calculated when applying allocation based on the energy content of the products (Table 2). The comparative LCA results when applying different allocation methods are showed in Table 3. The results indicate that the choice of allocation methods has important influence on the outcomes. Impacts are lager by switching from mass to energy content-based allocation. For example, ADP in the life cycle of soybean, jatropha, and microalgae based biodiesel increases $101.89 \%, 44.02 \%$ and $36.5 \%$ respectively when applying energy content-based allocation. The analogous results are also observed in other impact categories.

\section{Table 2}

The partitioning ratios between main- and co-products outputted in the life cycle system of biodiesel.

\begin{tabular}{lll}
\hline Products & $\begin{array}{l}\text { Net caloric } \\
\text { value }(\mathrm{MJ} / \mathrm{kg})\end{array}$ & $\begin{array}{l}\text { Partitioning } \\
\text { ratio }\end{array}$ \\
\hline Soybean oil & $37[53]$ & 0.395 \\
Soybean cake & $11.59[54]$ & 0.605 \\
Jatrophal oil & $37[53]$ & 0.466 \\
Jatropha seed cake & $18.2[55]$ & 0.534 \\
Algal oil & $37[53]$ & 0.737 \\
Alge residues & $10.83[56]$ & 0.263 \\
Biodiesel & $39.5[53]$ & 0.943 \\
Crude glycerol & $25.6[53]$ & 0.057 \\
\hline
\end{tabular}

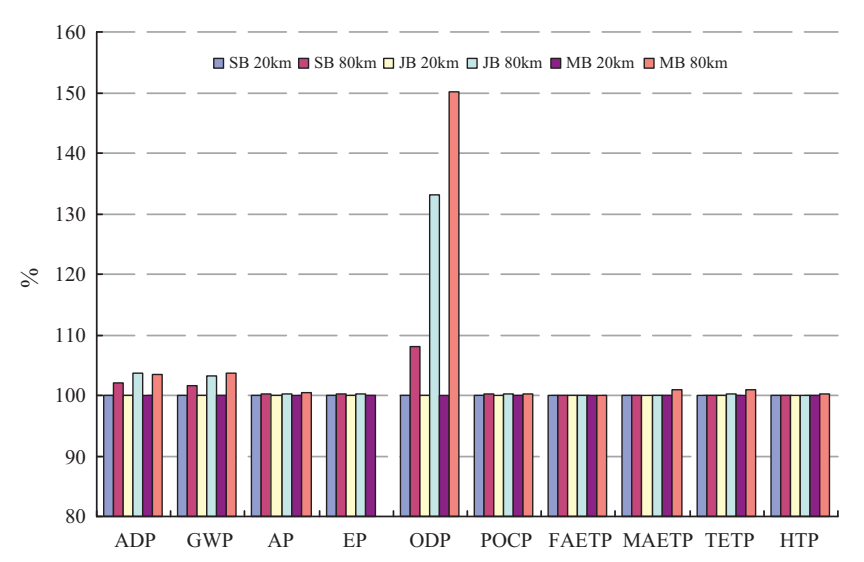

Fig. 5. Comparative LCA results when 20 - and $80-\mathrm{km}$ transport distances were assumed.

\subsubsection{Transport distance}

Since the jatropha and microalgae based biodiesel system under study has not been established in practice, and in order to compare the LCA results on an identical level, we have assumed the transport distances of biodiesel and different feedstock to be $20 \mathrm{~km}$. In this section, the sensitivity of transport distance is analyzed to see the influence of the transport section. To compare with, 20- and 80$\mathrm{km}$ transport distances are assumed. The comparative results are shown in Fig. 5.

It can be seen that the increase of transport distance leads to worse environmental performance in most impact categories, especially with regard to the level of ODP, GWP, and ADP. Increasing transport distances leads to higher demand of diesel used in lorries. Obvious consequences of the increasing extraction and use of diesel are $\mathrm{CO}_{2}$ emissions and fossil resources depletion. In fact, halogenated organic emission in crude oil extraction and refining has great destructiveness to ozone layer, making ODP to be the most sensitive impact category to transport distance change.

\subsubsection{Growth rate and oil content}

Jatropha and microalgae are newly developed feedstock for biodiesel production. Biomass yield and lipid content are two most important uncertain parameters in jatropha and microalgae agriculture, varying with land suitability, tree age, microalgae species, solar radiation, and temperature et al. According to research by $\mathrm{Wu}$ [57], investigation by He [58], and study by Chen [59], dry seed yield of jatropha in China ranges between 1500 and $5000 \mathrm{~kg} / \mathrm{ha}$, and seed oil content between $25 \%$ and $47 \%$. According to Sheehan [60] and Chisti [29], algal growth rate ranges between 5 and $50 \mathrm{~g} / \mathrm{m}^{2} \mathrm{~d}$, and lipid content between $15 \%$ and $80 \%$.

As shown in Figs. 6 and 7, larger impacts are generated when feedstock is with lower biomass yield and lipid content. The environmental impact is more affected when the biomass growth rate is at a lower level. Life cycle environmental performance of biodiesel is not influenced as lipid content changes when mass based allocation is applied. This is because the difference in the values of main and co-products is not considered. The influence of oil content on the environmental impacts is obvious when energy content based allocation is applied (Fig. 7).

Increasing growth rate and lipid content can reduce the life cycle environmental impacts of biodiesel made from microalgae. However, it is observed that lipid accumulation is likely to occur with nutrient depletion which happens when the growth rate slows [61]. Given that growth rate and lipid content conflict with each other, a trade-off must be made between growth rate and lipid content when choosing the suitable microalgae species for producing biodiesel. 
Table 3

Comparative LCA results when applying different allocation methods.

\begin{tabular}{|c|c|c|c|c|c|c|c|}
\hline & & \multicolumn{2}{|l|}{$\mathrm{SB}$} & \multicolumn{2}{|l|}{$\mathrm{JB}$} & \multicolumn{2}{|l|}{$\mathrm{MB}$} \\
\hline & & Mass allocation & Energy allocation & Mass allocation & Energy allocation & Mass allocation & Energy allocation \\
\hline $\mathrm{ADP}$ & kg antimony equiv. & $1.6627 \mathrm{E}-04$ & $3.3569 \mathrm{E}-04$ & $9.8160 \mathrm{E}-05$ & $1.3067 \mathrm{E}-04$ & $1.0581 \mathrm{E}-04$ & $1.4801 \mathrm{E}-04$ \\
\hline GWP & kg CO${ }_{2}$ equiv. & $3.4891 \mathrm{E}-02$ & $7.5718 \mathrm{E}-02$ & $1.7891 \mathrm{E}-02$ & $2.5073 \mathrm{E}-02$ & $1.6216 \mathrm{E}-02$ & $2.3088 \mathrm{E}-02$ \\
\hline $\mathrm{AP}$ & $\mathrm{kg} \mathrm{SO}_{2}$ equiv. & $1.4147 \mathrm{E}-03$ & $2.6821 \mathrm{E}-03$ & $9.0947 \mathrm{E}-04$ & $1.1441 \mathrm{E}-03$ & $6.5177 \mathrm{E}-04$ & $7.261 \mathrm{E}-04$ \\
\hline $\mathrm{EP}$ & $\mathrm{kg} \mathrm{PO}_{4}$ equiv. & $3.1410 \mathrm{E}-04$ & $6.4275 \mathrm{E}-04$ & $1.7751 \mathrm{E}-04$ & $2.3396 \mathrm{E}-04$ & $1.4613 \mathrm{E}-04$ & $1.8697 \mathrm{E}-04$ \\
\hline ODP & kg CFC-11 equiv. & $1.2483 \mathrm{E}-11$ & $2.9451 \mathrm{E}-11$ & $3.0068 \mathrm{E}-12$ & $4.3605 \mathrm{E}-12$ & $1.9860 \mathrm{E}-12$ & $2.7586 \mathrm{E}-12$ \\
\hline РOCP & kg ethylene equiv. & $7.9646 \mathrm{E}-05$ & $1.437 \mathrm{E}-04$ & $6.5995 \mathrm{E}-05$ & $8.5787 \mathrm{E}-05$ & $6.2964 \mathrm{E}-05$ & $8.3143 \mathrm{E}-05$ \\
\hline FAETP & kg 1,4-DCB equiv. & $1.9096 \mathrm{E}-02$ & $4.6652 \mathrm{E}-02$ & $1.3304 \mathrm{E}-02$ & $2.1747 \mathrm{E}-02$ & $6.2657 \mathrm{E}-04$ & $7.9271 \mathrm{E}-04$ \\
\hline MAETP & kg 1,4-DCB equiv. & $4.0884 \mathrm{E}+01$ & $8.5903 E+01$ & $2.6287 \mathrm{E}+01$ & $3.7095 \mathrm{E}+01$ & $2.2443 \mathrm{E}+01$ & $3.5599 \mathrm{E}+01$ \\
\hline TETP & kg 1,4-DCB equiv. & $3.4095 \mathrm{E}-04$ & $8.2536 \mathrm{E}-04$ & $2.2852 \mathrm{E}-04$ & $3.7021 \mathrm{E}-04$ & $2.8548 \mathrm{E}-05$ & $4.0775 \mathrm{E}-05$ \\
\hline HTP & kg 1,4-DCB equiv. & $1.2819 \mathrm{E}-02$ & $2.4854 \mathrm{E}-02$ & $9.2143 \mathrm{E}-03$ & $1.234 \mathrm{E}-02$ & $8.0430 \mathrm{E}-03$ & $1.069 \mathrm{E}-02$ \\
\hline
\end{tabular}

\subsubsection{Microalgae cultivation water recycling rate}

The nutrient use and emissions from $\mathrm{N}$ and $\mathrm{P}$ fertilizer application in microalgae cultivation while with different rate the harvest water is recycled are calculated according to the study of Yang [62], as Table 4 shows. Fig. 8 illustrates the life cycle environmental impacts changes of microalgae based biodiesel with different harvest water recycling rate.

The increase of microalgae harvest water recycling rate leads to better environmental performance in all impact categories, especially with regard to EP. Recycling harvest water reduces nutrient use and makes better control of fertilizers fate, which results in the reduction of fossil resources depletion and environmental emissions in nutrient production, and nitrate and phosphate leaching to ground water, and ammonia and $\mathrm{NO}_{x}$ to air from $\mathrm{N}$ and $\mathrm{P}$ fertilizer use, which contributes largely to EP.
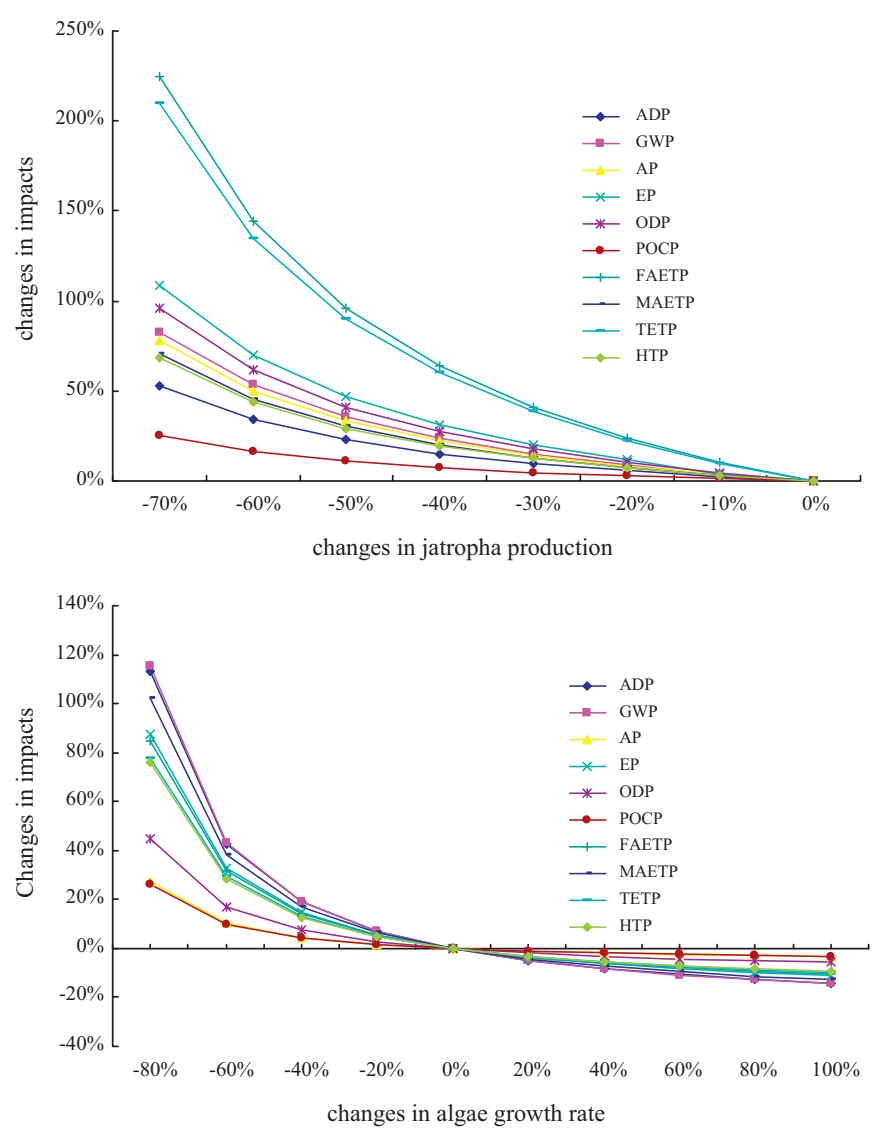

Fig. 6. Sensitivity analysis of growth rate.
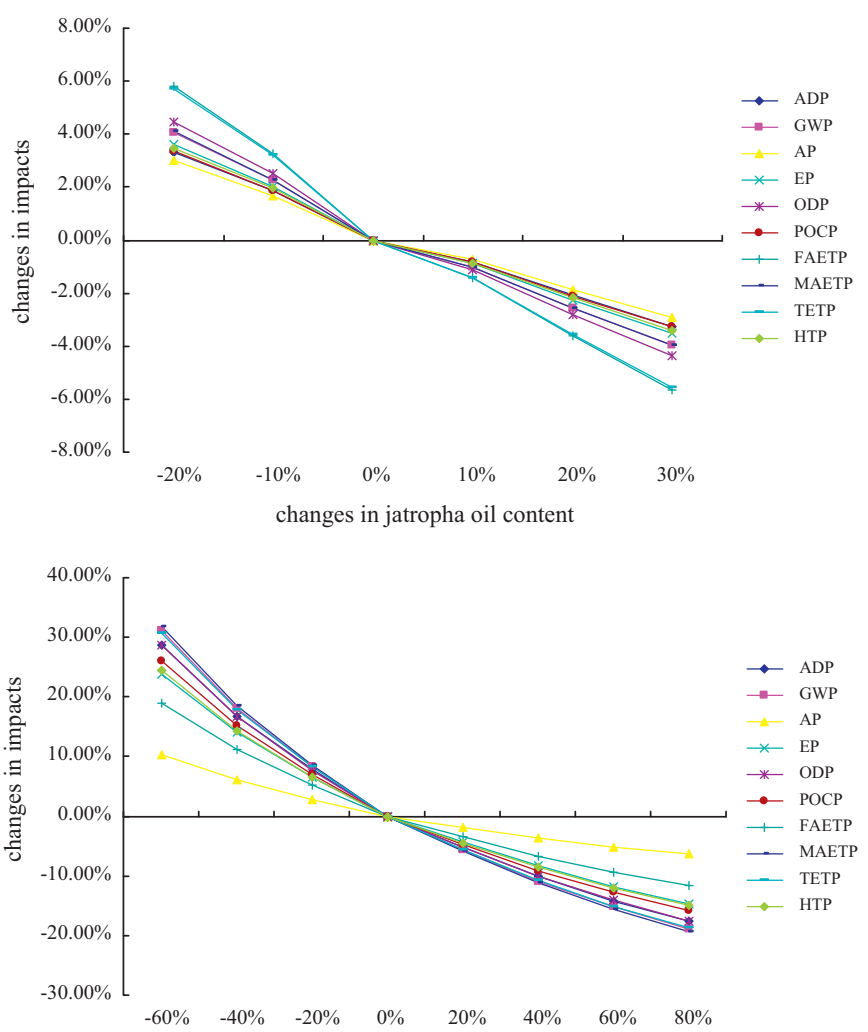

changes in microalae oil content

Fig. 7. Sensitivity analysis of oil content.

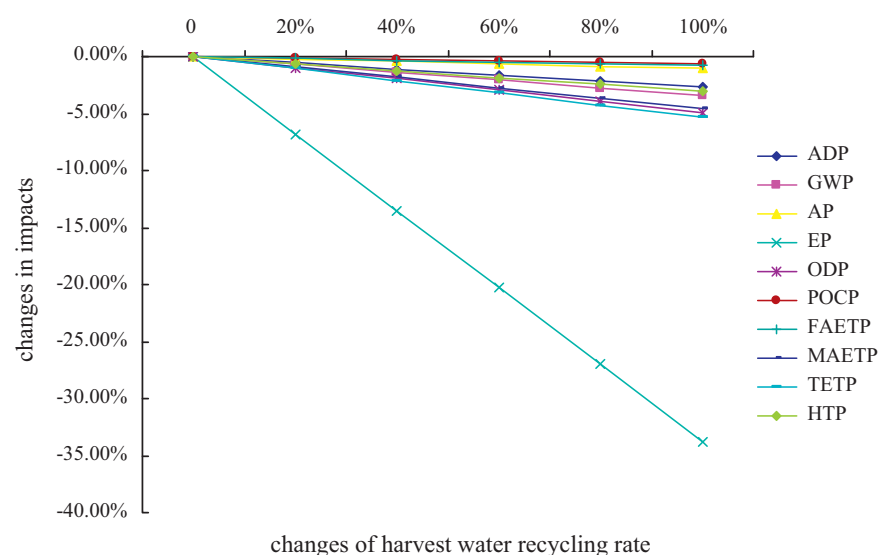

Fig. 8. Life cycle environmental impacts of microalgae oil based biodiesel while with different rate the harvest water is recycled. 
Table 4

The nutrient use and emissions from $\mathrm{N}$ and $\mathrm{P}$ fertilizer application with different harvest water recycling rate.

\begin{tabular}{|c|c|c|c|c|c|c|}
\hline Nutrient use and emissions & 0 & $20 \%$ & $40 \%$ & $60 \%$ & $80 \%$ & $100 \%$ \\
\hline $\mathrm{N}(\mathrm{kg})$ & 5.56 & 4.9484 & 4.3368 & 3.7252 & 3.1136 & 2.502 \\
\hline $\mathrm{P}_{2} \mathrm{O}_{5}(\mathrm{~kg})$ & 1.29 & 1.1481 & 1.0062 & 0.8643 & 0.7224 & 0.5805 \\
\hline Nitrogen volatilisation $(\mathrm{kg})$ & 0.0222 & 0.0198 & 0.0173 & 0.0149 & 0.0125 & 0.01 \\
\hline Nitrate (inorganic emissions to sea water) (kg) & 13.4900 & 10.7587 & 8.0691 & 5.3794 & 2.6897 & 0 \\
\hline Phosphate (inorganic emissions to sea water) (kg) & 0.7760 & 0.6204 & 0.4653 & 0.3102 & 0.1551 & 0 \\
\hline
\end{tabular}

The data are calculated according to [62]. When the harvest water is $100 \%$ recycled, the usage of these nutrients decreases by approximately $55 \%$.

\section{Conclusions}

In this study, the LCA methodology was used to evaluate the environmental performance of biodiesel produced from soybean, jatropha, and microalgae in China conditions. The assessment results indicate that producing and driving with soybean, jatropha, and microalgae based biodiesel fuel as a replacement of fossil diesel contributes to the reduction of abiotic depletion potential and global warming potential significantly, mainly due to the solar energy and $\mathrm{CO}_{2}$ uptake from environment by photosynthesis in biomass feedstock agriculture. The reduction of dependency on fossil fuels in biodiesel production leads to a better performance on ozone depletion potential. However, biodiesel as transport fuel performs worse regarding other environmental impacts, including photochemical oxidation, eutrophication, acidification, and human and eco-toxicity. Jatropha and microalgae are more competitive biodiesel feedstock compared to soybean in terms of all impacts due to the lower level of agricultural inputs per unit of oil produced. Sensitivity analyses show that the application of different allocation methods affects the LCA outcomes; increasing transport distance leads to worse performance, especially ozone depletion potential; increasing growth rate and lipid content can reduce the life cycle environmental impacts; recycling of harvest water lowers the environmental impact of microalgae based biodiesel, especially with regard to eutrophication.

The LCA results for these $10 \mathrm{mid}$-point impact categories of soybean, jatropha, and microalgae based biodiesel and fossil diesel are combined into a single score using global normalization references and weighting method based on ecotaxes. Compared with fossil diesel, the benefits offered by biodiesel derived from soybean oil, jatropha oil, and microalgal oil, in terms of fossil resources use, GHG emissions and destructivity to ozone layer, are offset by worse impacts in other categories, such as eutrophication, acidification, photochemical oxidation, and toxicity aspects. The LCA single score for these 10 mid-point impact categories of soybean, jatropha, and microalgae based biodiesel is 54, 37.2 and 3.67 times of that of fossil diesel, respectively. Careful management of biomass agriculture and biodiesel production, and improvements in energy structure and energy efficiency of China may be pathways to reduce these environmental impacts.

Although the LCA based analysis in this study represents a comprehensive view, it is not complete. The environmental assessment is based on a given set of impact categories. The overall life cycle environmental performance of producing and using biodiesel as transport fuel requires further research, in which several other critical impacts in biofuel LCA studies shall be considered, such as water and land use. Land use change can be accompanied by large amounts of GHG emissions from soils, as the studies of Fargione et al. [63] and Lapola et al. [64] show that GHG emissions from direct and indirect land use change may be much more than the annual greenhouse gas (GHG) reductions that biofuels would provide by displacing fossil fuels.

\section{Acknowledgements}

Research of this article has been supported by National Natural Science Funds (40901063) and Special Funding for Public Benefit Research of Environmental Protection Department (2008467087). Thank Chinese Academy of Sciences, National Natural Sciences Foundation of China and Ministry of Environmental Protection of the PRC for their assistance.

\section{References}

[1] Xinhua News Agency. China's oil import dependency firstly exceeds warning line; 2009. Available at http://news.xinhuanet.com/fortune/201003/29/content_13265670.html [March 29, 2009].

[2] Energy Information Administration. International energy outlook. Washington, DC: U.S. Department of Energy; 2009. Available online: http://www.eia.doe.gov/oiaf/ieo/index.html.

[3] Omer AM. Energy environment and sustainable development. Renewable and Sustainable Energy Reviews 2008;12:2265-300.

[4] Omer AM. Green energies and the environment. Renewable and Sustainable Energy Reviews 2008;12:1789-821.

[5] PRC State Development and Reform Commission. Medium and long-term development plan for renewable energy. Beijing: PRC State Development and Reform Commission; 2007.

[6] Demirbas A. Progress and recent trends in biodiesel fuels. Energy Conversion and Management 2009;50:14-34.

[7] Achten WMJ, Verchot L, Franken YJ, Mathijs E, Singh VP, Aerts R, et al. Jatropha bio-diesel production and use. Biomass and Bioenergy 2008;32: 1063-84.

[8] Li Y, Horsman M, Wu N, Lan CQ, Dubois-Calero N. Biofuels from microalgae. Biotechnology Progress 2008;24:815-20.

[9] Stephenson AL, Blottnitz H, Brent AC, Dennis JS, Scott SA. Global warming potential and fossil-energy requirements of biodiesel production scenarios in South Africa. Energy Fuels 2010;24:2489-99.

[10] Bernesson S, Nilsson D, Hansson P-A. A limited LCA comparing large- and smallscale production of rape methyl ester (RME) under Swedish conditions. Biomass and Bioenergy 2004;26:545-59.

[11] Harding KG, Dennis JS, von Blottnitz H, Harrison STL. A life-cycle comparison between inorganic and biological catalysis for the production of biodiesel. Journal of Cleaner Production 2008;16:1368-78.

[12] Lardon L, Helias A, Sialve B, Stayer JP, Bernard O. Life-cycle assessment of biodiesel production from microalgae. Environmental Science and Technology 2009;43:6475-81.

[13] Arvidsson R, Persson S, FrÖing M, SvanstrÖm M. Life cycle assessment of hydrotreated vegetable oil from rape, oil palm and Jatropha. Journal of Cleaner Production 2010;19:129-37.

[14] Papong S, Chom-In T, Noksa-nga S, Malakul P. Life cycle energy efficiency and potentials of biodiesel production from palm oil in Thailand. Energy Policy 2010;38:226-33.

[15] BP. Statistical review of world energy 2010. London: BP; 2010.

[16] Ma H, Oxley L, Gibson J. China's energy situation in the new millennium. Renewable and Sustainable Energy Reviews 2009;13:1781-99.

[17] PRC National Bureau of Statistics. China energy statistics yearbook. Beijing: China Statistical Publishing House; 2010. Available at http://www.stats.gov.cn/tjsj/ndsj/ [October 16, 2010].

[18] Chen H, Chen GQ. Energy cost of rapeseed-based biodiesel as alternative energy in China. Renewable Energy 2010.

[19] Hu Z, Tan P, Yan X, Lou D. Life cycle energy, environment and economic assessment of soybean-based biodiesel as an alternative automotive fuel in China. Energy 2008;33:1654-8.

[20] Dong X, Ulgiati S, Yan M, Zhang X, Gao W. Energy and eMergy evaluation of bioethanol production from wheat in Henan Province, China. Energy Policy 2008;36:3882-92.

[21] Ou X, Zhang X, Chang S, Guo Q. Energy consumption and GHG emissions of six biofuel pathways by LCA in (the) People's Republic of China. Applied Energy 2009;86:S197-208.

[22] Dong D, Zhao D, Liao C. Energy consumption analysis in life cycle of cassava fuel ethanol production and the advantages of the new technology in energy consumption. Transactions of the CSAE 2008;24:160-4 [in Chinese]. 
[23] Hou J, Zhang P, Wang Y, Yuan X. Life cycle assessment of energy consumption and $\mathrm{CO}_{2}$ emissions of bio-diesel made from food waste oil. Research of Environmental Sciences 2010;23:521-6 [in Chinese]

[24] Regan DL, Gartside G. Liquid fuels from micro-algae in Australia. South Melbourne: CSIRO; 1983.

[25] Benemann JR, Oswald WJ. Systems and economic analysis of microalgae ponds for conversion of $\mathrm{CO}_{2}$ to biomass. Berkeley: Department of Civil Engineering, University of California; 1996.

[26] Liu Y.Cultivation techniques and utilization value in Jatropha curcas L. Nonwood Forest Research 2006;24:74-6 [in Chinese].

[27] PE International. GaBi 4.3 Software. Leinfelden-Echterdingen: PE International; 2006.

[28] Hu Q, Sommerfeld M, Jarvis E, Ghirardi M, Posewitz M, Seibert M, et al. Microalgal triacylglycerols as feedstocks for biofuel production: perspectives and advances. Plant Journal 2008;54:621-39.

[29] Chisti Y. Biodiesel from microalgae. Biotechnology Advances 2010;25: 294-306.

[30] ECETOC (European Center for Eco-toxicology and Toxicology of Chemicals). Technical report no. 62. Ammonia emissions to air in Western Europe. Brussels; 1994.

[31] Bentrup F, Kusters J. Methods to estimate to potential N emissions related to crop production. In: Agricultural data for life cycle assessments. The Hague, the Netherlands: Agricultural Economics Research Institute (LEI); 2000.

[32] IPCC (Intergovernmental Panel on Climate Change). $\mathrm{N}_{2} \mathrm{O}$ emissions from managed soils, and $\mathrm{CO}_{2}$ emissions from lime and urea application. In: IPCC guidelines for national greenhouse gas inventories. Hayama: National Greenhouse Gas Inventories Programme; 2006.

[33] Rossier D, Ecobilan. Adaptation de la methode ecobilan pour la gestion environnementale de l'exploitation agricole. Lausanne: Service Romand de Vulgarisation Agricole; 1998.

[34] Van Calker KJ, Berentsen PBM, de Boer IMJ, Giesen GWJ, Huirne RBM. An LPmodel to analyze economic and ecological sustainability on Dutch dairy farms: model presentation and application for experimental farm "de Marke". Agricultural Systems 2004;82:139-60.

[35] Song X, Yu J. Study on cost of oil processing. China Oils and Fats 2003;28:62-4 [in Chinese].

[36] Li C, Jiang L, Cheng S. Biodiesel: green energy resource. Beijing: Chemical Industry Press; 2005 [in Chinese].

[37] Di X, Nie. Z, Zuo T. Life cycle emission inventories for the fuels consumed by thermal power in China. Chinese Environmental Sciences 2005;25:632-5 [in Chinese].

[38] Yuan B, Nie Z, Di X, Zuo T. Life cycle inventories of fossil fuels in China (II): final life cycle inventories. Modern Chemical Industry 2006;26:5-7 [in Chinese].

[39] PRC State Environmental Protection Administration. HJ/T188-2006: cleaner production standard-nitrogenous fertilizer industry. Beijing: China Environmental Science Press; 2006.

[40] PRC National Development and Reform Commission. Clean production evaluation indices-phosphatic fertilizer industry. Beijing: NDRC; 2010.

[41] Zhang G. Economic analysis research of project of ultra-ten-thousand tons of sea water extraction Bittern comprehensive utilization of potassium sulfate. Qingdao: Ocean University of China; 2009.

[42] PRC National Development and Reform Commission. Clean production evaluation indices-agrochemical industry. Beijing: NDRC; 2010.

[43] Cheng Y. Analysis for clean production of methanol. Environmental Protection and Circular Economy 2008;5:22-7.

[44] Guine'e J, Gorree M, Heijungs R, Huppes G, Kleijn R, de Koning A, et al. Life cycle assessment: an operational guide to the ISO standards. Part 1 and 2. Den Haag, The Netherlands: Ministry of Housing, Spatial Planning and Environment (VROM) and Centre of Environmental Science (CML); 2001.

[45] Guinée JB, Gorree M, Heijungs R, Huppes G, Kleijin R, de Koning A, et al. Handbook on life cycle assessment operational guide to the ISO standards. Dordrecht: Kluwer Academic Publishers; 2002.
[46] ISO. ISO 14044: environmental management: life cycle assessment-requirements and guidelines. Second edition Geneva: International Standardization Organization; 2006.

[47] Reap J, Roman F, Duncan S, Bras B. A survey of unresolved problems in life cycle assessment. International Journal of Life Cycle Assessment 2008;13:374-88.

[48] Sleeswijk AW, van Oers LFCM, Guinée JB, Struijs J, Huijbregts MAJ. Normalization in product life cycle assessment: an LCA of the global and European economic systems in the year 2000. Science of the Total Environment 2008;390:227-40.

[49] Finnveden G, Hauschild MZ, Ekvall T, Guinee J, Heijungs R, Hellweg S, et al. Recent developments in life cycle assessment. Journal of Environmental Management 2009;91:1-21.

[50] Finnveden G, Eldh P, Johansson J. Weighting in LCA based on ecotaxes-development of a mid-point method and experiences from case studies. International Journal of Life Cycle Assessment 2006;11:81-8.

[51] Jolliet O, Margni M, Charles R, Humbert S, Payet J, Rebitzer G. Rosenbaum R. IMPACT 2002+: a new life cycle impact assessment methodology. International Journal of Life Cycle Assessment 2003;8:324-30.

[52] ISO. ISO 14040: environmental management: life cycle assessment principles and framework, Second edition. Geneva: International Standardization Organization; 2006.

[53] Liu S, Sun D, Wan S, Ding G, Qin P. Emergy evaluation of a kind of biodiesel production system and construction of new emergy indices. Journal of Nanjing University (Natural Sciences) 2007;43:111-8 [in Chinese].

[54] Yue L, Qiao S. Study on nutritive value of rapeseed cake. Feed and Husbandry 2009;3:13-6 [in Chinese].

[55] Whitaker, Heath. Life cycle assessment of the use of jatropha biodiesel in Indian locomotives. NREL Report No. TP-6A2-44428; 2009. On line at: http://www.nrel.gov/docs/fy10osti/47462.pdf.

[56] Liu J, Ma X. LCA and carbon recycle analysis on electricity production from microalgae by gasfication. Acta energiae solaris sinica 2008;29:1415-8 [in Chinese].

[57] Wu W, Huang J. Economical feasibility analysis of jatropha plantation for biodiesel production. Chinese Rural Economy 2010;7:56-63 [in Chinese].

[58] He Y. Investigation of jatropha biodiesel industrialization in China. Biotechnology and Business 2008;5:100-3 [in Chinese].

[59] Chen F, Xu Y. Research and development progress of jatropha biodiesel. Biotechnology and Business 2009;5:54-60.

[60] Sheehan J, Dunahay T, Benemann J, Roessler P. A look back at the US department of energy's aquatic species program-biodiesel from algae. National Reneweable Energy Laboratory; 1998, http://www.nrel.gov/biomass/pdfs/24190.pdf.

[61] Goldberg IK, Cohen Z. The effect of phosphate starvation on the lipid and fatty acid composition of the fresh water eustigmatophyte Monodus subterraneus. Phytochemistry 2006;67:696-701.

[62] Yang J, Xu M, Zhang X, Hu Q, Sommerfeld M, Chen Y. Life cycle analysis on biodiesel production from microalgae: water footprint and nutrients balance. Bioresource Technology 2010;102:159-65.

[63] Fargione J, Hill J, Tilman D, Polasky S, Hawthorne P. Land clearing and the biofuel carbon debt. Science 2008;319:1235-8.

[64] Lapola DM, Schaldach R, Alcamo J, Bondeau A, Koch J, Koelking C, et al. Indirect land-use changes can overcome carbon savings from biofuels in Brazil. Proceedings of the National Academy of Sciences of the United States of America 2010;107:3388-93.

Jian Hou, Doctor Candidate, was born in 1985 at Hunan Province, and graduated from Lanzhou University in 2007. From November 2008 till now, she has been studying in Qingdao Institute of Bioenergy and Bioprocess Technology, CAS.

Peidong Zhang, Associate Prof., was born in 1977 at Gansu Province, received his PhD degree from Lanzhou University in 2006. From 2002 to 2007, he had been working in Lanzhou Commercial College. From January 2008 till now, he has been working in Qingdao Institute of Bioenergy and Bioprocess Technology, CAS, and his research work focuses on strategic research and assessment. 